\title{
Perspectives
}

\section{Language and Living: Getting and Giving}

\section{Mary Ashworth}

\section{Introduction}

Twenty years ago, almost to the day, a group of ESL teachers who held positions in their provincial ESL organizations met in Toronto to discuss the possibility of forming a national ESL organization. But the ground had been laid in the previous decade. Today I want to take you back in time so that newcomers to the profession in Canada will have a sense of how we have got to where we are, but, more importantly, I want to leave all of you with a sense not of where the future may take you, but where you could guide the future.

It's 30 years since I became involved in ESL, and I have seen many changes. There were very few trained ESL teachers in those days, and those who were trained had taken the Ontario government's training course in Toronto or the University of British Columbia's ESL course given in the summers of 1967 and 1968 by a visiting professor from London University. There were no ESL organizations, but TEAL (BC Association of Teachers of English as an Additional Language) was about to be born. As I look back I can see that we've come a long way, but not far enough.

Part I of my talk-Language and Living-will look at the contribution you and others have made to enable newcomers to Canada-and some who were born here--to learn English and Canadian ways well enough that they could live happy, useful lives. Part II-Getting and Giving-will look forward to what it is that teachers, students, and citizens need to "get" in the years ahead that they may "give" to each other, to their communities, and to Canada that our country may grow in peace and harmony and be an example to others.

\section{Part I: Language and Living}

How did we get from then to now? To a point where our students, adults, and children, can learn not just language, but culture, subject matter, a vocation, and to learn it all well enough to become part of different communities: the school community, the local community, the community of work, and the national community? I'll draw on my memories and those of other people. 
In 1969 I asked my department head at UBC if I could offer Education 478, Teaching English as a Second Language, during the winter session, 19691970. The Faculty of Education was reluctant to let me do it, feeling it was unlikely that anyone would turn up, so they stuck me in a windowless basement room that would have taken 15 comfortably, but I had 27 . The summer of 1970 brought 23, and for the 1970-1971 winter session the same windowless room was home to 28 students! Within a few years the Faculty was offering two sections of Education 478 in each of the winter, spring, and summer sessions, and I was teaching all of them until Bernie Mohan arrived in 1974. During the early 1970s I had a great time traveling all over BC and across the prairie provinces putting on workshops in ESL. Those were the days when some people, like one of my colleagues, believed in all seriousness that immigration to Canada was very soon going to stop. "What are you going to do, Mary," one professor asked me, "when there is no more ESL?" I laughed politely and extricated myself from the corner into which he had pushed me and went about my business of finding more and more classrooms where student-teachers could complete a practicum in ESL under either a trained ESL teacher or, failing that, under one who had done a good job on her own of learning the principles of the ESL methodology then in vogue and putting them into practice.

There were very few textbooks for teachers or for adult or K-12 students. Carson Martin's text English for New Canadians written for teachers of adult ESL students could be found in many K-12 ESL classes. You have to be grey-haired to remember that text, let alone to have used it! But he was following the principles then in vogue: easy to difficult grammatical structures using various situations-shopping, banking, visiting the doctor, and so forth. Australia published Situational English for adults. England put out a series of books for children, and then went into hibernation so far as children were concerned, while the British Council became well known around the globe and was good enough to send speakers to our conferences at no charge, and still helps BC through the Patricia Wakefield Scholarship. In those days the total display of ESL texts could have been accommodated comfortably on one table. Over the years the famine has turned into a feast!

As time passed, teacher training institutions across Canada mounted courses for teachers in ESL, Applied Linguistics, and related topics and offered certificates, diplomas, and graduate degrees. The teaching profession has, in my view, done well in expanding opportunities for training in ESL. But unfortunately, particularly in the school systems, authorities have not always been ready to hire trained ESL teachers and to put them in charge of ESL classes, departments, and programs. Most provinces had to wait some years before provincial or district ESL consultants were appointed-and too often returned too soon to the classroom because of lack of funding. 
An important milestone in our past was, of course, the formation of TESL Canada. This organization could not be established until at least half the provinces had formed their own ESL association. BC TEAL was the first to organize its ESL teachers. With the help of the BC Teachers' Federation it held an historic meeting on June 15, 1967, 30 years ago. Twenty people attended and discussed, amended, and approved resolutions covering the proposed constitution and the objectives of the organization. Other provinces followed suit and by 1977 the time was ripe for a national organization. With the help of a grant from the federal government, an inaugural meeting was held in connection with the Ontario ESL conference in October 1977. A steering committee was set up, and a year later the constitution and objectives were in place.

Now, 20 years after the inaugural meeting, let me remind you of the objectives of TESL Canada, and you can ask yourself, "Have we attained these objectives? What should we concentrate on in the next two decades." Here are the objectives as written by the Advisory Committee of the new TESL Canada in October 1977.

1. To promote communication among the various jurisdictions.

2. To encourage and support the promotion of TESL/D policies compatible with the aims and objectives of the federation.

3. To encourage the establishment of associations in jurisdictions where none exist.

4. To foster scholarship and research in areas related to TESL/D.

5. To coordinate the dissemination of information in fields related to TESL/D.

6. To allow for representation of its membership at the international level.

The first copy of the TESL Canada Journal, Vol. 1, was published in January 1984 under the editorship of Susan Parks of Concordia University. By then TESL Canada consisted of nine full members-provincial organizationsand two associate members. Ten pages at the back advertised training programs and texts. The editor wrote: "TESL Canada Journal will provide an outlet in both official languages for papers and research from within Canada and abroad. First and foremost, however, the Journal will serve to communicate developments within or relevant to our profession in Canada, thus realizing one of TESL Canada's primary objectives."

The TESL Canada Journal has served us well since 1984. One of the articles in the first edition is entitled "English Language and Life" - pretty close to the theme of this conference "Language and Living." David Cooke of York University interviewed Kathy Bond-Stewart, a South African, who was teaching English in the then young state of Zimbabwe. Bond-Stewart taught a variety of students, South African black workers, Zulu children, and women ex-combatants in Zimbabwe. These women had been scarred by the whole war experience. A lot of them were depressed, coming back, expecting 
a lot, finding very little, so writing became almost urgent for them, she felt, to explore some of their very painful experiences from the past, trying to situate them within a wider context of life (Bond-Stewart, 1984). Some immigrant women in Canada have had painful experiences and have appreciated your help in finding their place in Canadian society.

The Journal has enabled teachers across Canada to learn what is going on in other provinces. In March 1987, Gordon and Mary Selman wrote on "Leadership in the Public Sector: ESL for Adults in BC 1976-1983." British Columbians will remember what a great leader Mary was, becoming the first ESL consultant for the province for adult ESL programs. Leadership is a topic I will return to later. The March 1990 edition printed a brief presented to the Task Force on Multiculturalism by SCENES (Saskatchewan Council for Educators of Non-English Speakers). The fundamental concern that SCENES wanted to draw to the attention of the Task Force was the lack of involvement of the provincial government in the provision of language training. The brief laid out the background to language training in Saskatchewan, the problems of funding, the efforts made toward a comprehensive and provincial ESL policy and more (Rubrecht, 1990). The importance of the inclusion of this brief in the Journal was that it let other provinces know what was happening in a province that had low numbers of ESL students compared with, say, Ontario. Having low numbers of students spread out geographically presents its own problems different from those of Ontario and $\mathrm{BC}$ who have high numbers of ESL students often clustered in specific areas.

The TESL Canada Journal has certainly been worth the time and money spent on it. The last article I want to draw your attention to compares and contrasts certification and accreditation of ESL teachers in BC and Alberta by Dianne Keevil Harrold in the Winter 1995 edition. The article shows how far we have come from the days when, provided you spoke English, some administrators believed you could teach it (Harrold, 1995). Both TEAL and Alberta TESOL require a minimum of an undergraduate degree and a set number of hours taking ESL training for their lowest professional certificate. The author also covers the state of accreditation in Saskatchewan, Prince Edward Island, New Brunswick, and Newfoundland: a very, very useful article, which will enable provinces to look again at accreditation without having to recreate the wheel.

In the summer of 1996, the TESL Canada Certification Special Interest Group was formed with the purpose of working toward the creation of a national certification document which will provide national standards for institutions and professionals in ESL (Begin, 1996).

TESL Canada is concerned about the development of distance learning graduate level credit courses in TESL and related fields of study by Canadian universities for students overseas, and has become more involved in the Canadian Language Benchmarks and Assessment Project along with some 
provisional organizations. TESL Canada has links to five overseas TESL organizations in Thailand, Korea, Japan, England, and Australia.

I hope you all read the TESL Canada Bulletin, which not only fills you in on what TESL Canada is doing, but also provides interesting reports from the various provinces and territories. From the Spring 1997 Bulletin we learned that Alberta's current membership is 543; that Manitoba is working on the Canadian Language Benchmarks; that Saskatchewan has set up an accreditation board; that SPEAQ has celebrated its 25th anniversary; that Nova Scotia is concerned about its immigrant children and has set up an Action Group for Newcomers; that Ontario has completed phase two of its accreditation research project; and that New Brunswick is forming a committee to approach school principals with offers of assistance to help second language students in schools. There was more, but that list is sufficient to show that our provincial and territorial associations are actively working for second language learners, whether born in Canada or overseas.

So here we are, 20 years on from the inaugural meeting in 1977.

\section{Part II: Getting and Giving}

I have been retired now for nine years. I have tried to keep up-to-date with changes-good and bad - that have occurred in ESL, but it is not always easy when one is not in constant day-to-day contact with the field. Today I am going to take the opportunity in this Part II to look ahead and draw your attention to four areas I believe to be important to ESL across Canada, and therefore important to Canada, as immigrants have in the past and will in the future play an important role in building a country we can all be proud of.

The four topics I am including in Part II-Getting and Giving-are, first, Knowledge, which involves Getting-Getting Knowledge. The second topic Leadership involves Giving-Giving of self for the benefit of others. Topic three, Funding, and topic four, Peace, both involve Getting and Giving.

\section{Knowledge}

Wordsworth wrote:

Who, with a natural instinct to discern

What knowledge can perform, is diligent to learn.

(Character of a Happy Warrior)

Once people realize how knowledge can help to ease their daily tasks, they are ready to learn and to become "Happy Warriors," Wordsworth's term for those who follow his advice and are "diligent to learn." Increased knowledge about teaching and learning English as a second language comes from research in Canada and abroad, which is carried out by academics in our universities and teachers in our schools and colleges-but it must be passed on through workshops, seminars, college and university courses, and articles 
in journals. Teachers cannot call themselves professionals if they do not have a firm grasp of the principles of teaching ESL, and if they do not have a creed, a set of beliefs, which underlies their everyday classroom practices. Principles come from the head; beliefs from the heart. Good teaching relies on both the head and the heart.

Much has changed in the last 30 years in ESL in methodology and in the role of the ESL teacher. The seniors among you-by age, not necessarily by seniority-will remember the Audio-Lingual Approach with its emphasis on repetition; "Listen and repeat," said the teacher, and the students listened and repeated many times, "My name is __... Your name is __.." and, of course, "Would you like a cup of coffee?" etc., etc., because B.F. Skinner, a behaviorist, said that's how students learn a second language, by habit formation. Teachers grew clever at finding ways to make the repetition palatable. Then came Noam Chomsky with very different views on second language learning - and the Audio-Lingual Habit theory went out of the window, and in came a multitude of different theories and approaches: The Silent Way, Total Physical Response, The Natural Way, the Cognitive-Code Theory, Community Language Learning, and on and on. No theory is perfect. It exists only until another theory replaces it.

Right now the favored approach is Content and ESL, or simultaneous Content Learning and Language Learning. The three major methods are CALLA (Cognitive Academic Language Learning Approach) from Chamot and Uhl; Mohan's "Knowledge Framework"; and Kidd and Marquardson's FORESEE (or number 4, letter C), the four C's standing for Communication, Cognitive-Academic Language Development, and Content Instruction in the Classroom.

New technology has given us new classroom practices. I heard Neil Postman being interviewed on the radio a few weeks ago. In 1992 he published a book entitled Technopoly, which deals with the effect of technology on students. In the interview he said that teachers must ask two questions: (a) What does technology do in the classroom? and (b) What does technology undo in the classroom? Important questions as we get deeper into the age of the computer.

The role of ESL teachers has changed considerably, particularly in the school systems, from the days when ESL teachers shut their doors firmly, pulled down the blind, and did what? They kept it a secret! Classroom teachers would often ask me, "What goes on in there?" But now ESL teachers are expected to share their knowledge, to be consultants, facilitators, workshop leaders, and counselors as well as teachers.

Teacher training and teachers' organizations are the twin pillars which have supported the steady growth in professionalism in ESL, which has, in turn, raised the status of ESL in the teaching profession such that ESL teachers now vie with other teachers for prestigious awards. This spring Catherine 
Eddy, who set up and runs the Oakridge Reception and Orientation Centre in Vancouver, this year received the G.S. Fergusson Award from the British Columbia Teachers' Federation for her outstanding contribution to teaching, an unthinkable event 20 years ago, and so very well deserved.

It is not just teachers who need knowledge of ESL. Administrators, counselors, learning assistants, volunteer workers, multicultural workers, psychologists, speech therapists, special education teachers, office staff all need some knowledge of ESL and the settlement process, but the kind and depth of knowledge will vary according to the needs of each position. Getting knowledge helps to alleviate frustration, low morale, and burnout, and to bring together all who have a concern for non-English speaking children and adults. Who will provide this knowledge for these various groups? Why, you! By your presence here you have shown that you value knowledge and that you have leadership qualities, so let's move on to Topic \#2, Leadership.

\section{Leadership}

As some leaders grow old, others must step in to take their places. Leadership entails a lot of giving - time, energy, knowledge-but it is preceded by a lot of getting: getting knowledge and getting the ability to work with others and to step into the limelight, even though at first it may blind you. When I entered ESL, there was an American teacher, Mary Finocchiaro, who was a highly respected leader in ESL. In 1940 she began her career in ESL teaching students at New York City High School. Previous to this she had taught romance languages. Mary set out to develop new methods and materials for ESL. She published a book English as a Second Language: From Theory to Practice. It contained minimal pair drills, and I bet some of you don't know what they are! There were oral drills: substitution, expansion, deletion, transformation, replacement, restatement, reduction, integration, and progressive replacement using sentences like "The pencil is red" or "Do you like salad?" and, of course, "Would you like a cup of coffee?"-up-to-date exercises for the time. Her book was used all over the world to teach children and adults. Mary gave freely of her time to talk to teachers struggling to teach English to non-English speakers. The first time I met Mary was at an ESL conference in Toronto put on by the Ontario government in the early 1970s, as there was at that time no Ontario ESL organization. There she stood, chatting with a small group of Ontario ESL teachers. As I passed she said, "Does anyone have a pair of nail scissors?" Well, it so happened I did, and I quickly got them out. I couldn't let an opportunity to meet Mary Finocchiaro slide by. She gave me her hand and I clipped the offensive nail. She thanked me and we parted. I thought afterward that I should have kept the little bit of nail as a souvenir, but I was to get to know Mary better in the years to come. She set an example of leadership. She wrote about ESL and talked about ESL and gave advice about ESL and encouraged ESL teachers to work hard at their jobs because 
their work was so important. She made you feel good-if you didn't feel good when she started to talk, you did by the time she got through.

Everyone can lead-in different styles, different directions, for different reasons. If you are not now in a leadership role, I beg you to consider what your contribution could be and how you could give it. Nothing will build ESL programs faster and better than good leadership-at all levels.

Two immigrants have served this province well as leaders. David Lam from Hong Kong was our excellent Lieutenant-Governor for five years, and Ujjal Dosanjh, a graduate of my Education 478 class (Teaching ESL) in the summer of 1973, who is now BC's Attorney-General.

\section{Funding}

Funding! What can I say about funding? It's here one day and gone the next-at the whim of government. And that's no way to run programs-educational programs of any kind need stable and sufficient funding. I hear cries from some members of the public that immigrant children should either learn English before they come here or their parents should pay fees for them to learn English at a special school which they would have to attend before being admitted to a public school. Similarly, these people expect immigrant adults to have learned English before they arrive or to attend fee-paying classes. Any suggestion that refugees and many independent immigrants have neither the opportunity to become fluent in English before they arrive nor the ability to pay fees here is usually met with a shrug of the shoulders"Too bad" and off they go, unaware of what it costs an immigrant now just to have his or her papers processed, and uninformed about Canada's continuing need for immigrants.

A recent report (1997) called "Immigration to Canada: Youth Tonic for an Aging Population" by the Vancouver-based Urban Futures Institute says: "The long-term financial sustainability of Canada's pension plans, health care, income redistribution programs and other social services are dependent upon Canada having its current, or a higher, level of immigration in the future." The study recommends that immigration should increase by $30 \%$ to 300,000 newcomers a year, and suggests that Canada reduce its foreign aid spending to the level of other Western countries, that is, to about $0.3 \%$ of gross domestic product, and use the money saved, about $\$ 950$ million a year, to increase spending on immigration services without any tax increases (Griffin, 1997).

TESL Canada must continue its Awareness Campaign begun in 1991. The general public needs to understand that (a) many immigrants come here with skills we need - but we haven't had to pay the cost of training them; (b) once employed, immigrants pay taxes, and statistics show that they draw less from welfare than adults born in Canada; (c) if we are to think of ourselves as a compassionate country-and I hope we will-then we must 
prepare newcomers for the communities of work and education and for social interaction.

You must speak up for your students, and if you are not sure how to go about it, I refer you to my "Twenty Axioms for Making Educational Change" which you will find in my 1985 book Beyond Methodology (Ashworth, 1985). The last axiom says, "Be prepared to hurt," because if you want to make changes in society you will be vulnerable to personal attack. ESL teachers have, in my view, for many years proved strong advocates for their students. That advocacy must continue. If it doesn't, the progress made in the last three decades will discontinue, and your jobs and your students' futures will all be put in jeopardy.

\section{Peace}

Here in Canada we are engaged in an experiment regarding our way of life that could be an example-a good example-for many nations of the world. The ancient Greeks lived in city states comprising people of one ethnic group speaking one language. The city states merged into nation states, still with one dominant race, one dominant language. Since World War II many single-race, single-language nation states have seen their make-up change as they have accepted refugees and workers from other lands, speaking other languages and looking different. We are at the forefront of an attempt to create a multicultural, multilingual nation state-no, we didn't make a conscious decision to do that-it grew upon us as we changed our immigration laws, particularly in 1967, to make it possible for people of third-world countries and people from Asia to enter Canada as immigrants, refugees, or family members.

Europe is on the edge of creating a United States of Europe. Will we see in the years ahead a United States of the Americas? or a United States of Asia? and will these large conglomerates learn to live at peace within their borders and with each other? Or are we programmed to break into a world war every few decades? On September 3, 1939, my parents and I listened to Neville Chamberlain finish his talk to the British people with the words, "And so we are at war with Germany." My Mother burst into tears and said, "Not twice in a lifetime." For both my parents had served in the forces in World War I, and both would serve again, but this time in civilian roles. From September 3 on we were never a family again.

Today's and tomorrow's children will grow up in a world very different from our world, but you, through your chosen profession of teaching, by giving your students control of language, the ability to think critically, and a sense of friendship toward and responsibility for others, are laying the groundwork for changes that must surely come if we are to prevent future wars from killing and maiming millions of people who want nothing more than to live in peace with a roof over their heads, enough to eat, and the 
chance to live lives rich with opportunities to serve others and to be served by them.

An article in the July 12, 1997 edition of the Globe and Mail said: "The British Empire may be in full retreat with the handover of Hong Kong. But from Bengal to Belize and Las Vegas to Lahore, the language of the sceptred isle [English] is rapidly becoming the first global lingua franca." The ending of the friendship between China and the Soviet Union some years ago, the break up of the Soviet Union, and the admission of three Eastern European countries to NATO has increased the need for millions of people to learn English.

TESOL has had people working in the area of Peace Education. What can TESL Canada do to help bring in a millennium of peace and progress? What role can TESL Canada play within Canada to ensure that the citizens of this multicultural, multilingual land live at peace with each other? I have questions but you must find the answers-I am retired!

Thank you for all you have done for the ESL profession and for ESL students, and thank you for all I know you will do in the years ahead.

\section{References}

Ashworth, M. (1985). Beyond methodology. London: Cambridge University Press.

Begin, S. (1996, December). TESL Canada certification special interest group report. TESL Canada Bulletin, p. 7.

Bond-Stewart, K. (1984). In conversation with David Cooke "English language and life." TESL Canada Journal, 1(1), 87-92.

Griffin, K. (1997, August). Report calls for 300,000 new immigrants a year. The Vancouver Sun.

Harrold, D.K. (1995). Accreditation/certification for adult ESL instructors in Canada: An overview. TESL Canada Journal, 13(1),37-62.

Rubrecht P., with Vaid, A., Woloshyn, D., Craig, H., Anthony, E., Heit, M., \& Dowhaniuk, H. (1990). SCENES brief presented to the Task Force on Multiculturalism. TESL Canada Journal, 7(2), 95-102. 